\title{
Tensile Strength Properties of Rice Husk-Rice Husk Ash Filled Plastic Drinking Bottle Waste Hybrid Composite with the Addition of Glycerol as Plasticizer
}

\author{
Maulida Lubis, Faisal Bukhory Harahap \\ Department of Chemical Engineering, Engineering Faculty, University of Sumatera Utara, \\ Jl. Almamater Kampus USU Medan 20155, Indonesia
}

\begin{abstract}
This study aims to determine the tensile strength properties of rice husk-rice husk ash filled plastic drinking bottle waste hybrid composite with the addition of glycerol as plasticizer. Hybrid composite was made using extruder at $265{ }^{\circ} \mathrm{C}$ by mixing plastic drinking bottle waste with 100 mesh particle size of rice husk and rice husk ash with the ratio between matrix and filler 95/5, 90/10 and $85 / 15(w / w)$ and glycerol as a plasticizer added as much as 3\% of the volume plastic bottle waste on each ratio, and then it was processed using hotpress at $265^{\circ} \mathrm{C}$ for 5 minutes. Results of testing the tensile strength properties indicate that plastic drinking bottle waste hybrid composite filled by rice husk -rice husk ash with the addition of glycerol in the ratio of 95/5 obtained maximum tensile strength of 2,717 MPa, a Young's modulus value of $98964 \mathrm{MPa}$, elongation at break of 2.603\%. Results of SEM analysis on plastic drinking bottle waste hybrid composite filled by rice husk ash-rice husk with addition of glycerol in the ratio of 95/5 shows spread evenly on the surface of the filler matrix.
\end{abstract}

Keywords: hybrid composite, rice husk ash, rice husk, glycerol, tensile strength

\section{Introduction}

Nowadays, material technology has been developed rapidly. It is due to the increase of needs on materials that can meet particular requirement. One of the material technology product is polymer composite material. The easy forming ability, good strength and the advantage on strength : weight ratio, motivate the use of polymer composite as replacement for conventional metal material at various products [1].

Hybrid composite often related with fiber reinforcing material which was based on resin raw material. It was made by joining two kinds of fiber into single matrix. This concept was the simple extention from composite principle which combine two or more material to optimize the selling price by utilizing its best quality while reducing the unwanted effects. The combination of various material can also be called as hybrid [2].

Waste was the consequency of human activity. As the population and life style increased, the waste volume produced was also increased. Most of the waste produced were household waste which contained organic and anorganic materials. From the two categories of waste, it was known anorganic waste had more difficult to handle than the organic waste. The anorganic waste could not be degraded easily by nature and could become a serious land pollution problem. One of the examples of anorganic waste was plastic waste [3].

Plastic waste has become main problem in society and can be found in various places, especially in waste disposal. Plastic waste can cause environmental pollution because of its low biodegradability [4].
Paddy was one of main agricultural products in agricultural nations, especially in Indonesia. Rice husk was abundant byproduct from paddy grinding process. It was used as fuel for combusting red stone, cooking or disposing as such. The inappropriate rice husk handling would cause evironmental pollution. Previous research had reported that approximately $20 \%$ of paddy weight were rice husk and $13-29 \%$ of the husk composition were rice husk ash which were produced by combusting the husk. Generally, silica $\left(\mathrm{SiO}_{2}\right)$ composition value in rice husk ash was $94-96 \%$. If this value near or below $90 \%$, it was probably cause by contamination of other substance with low silica composition. Rice husk ash produced from controlled combustion at high temperature $\left(500-600^{\circ} \mathrm{C}\right)$ will produce silica ash that can be utilize for various chemical process [5].

In this study, glycerol was chosen as plasticizer because it was one of plasticizers that had been widely use and proved to reduce internal hydrogen bond effectively so that the intermolecular distance would increase [6].

The objective of this study was to determine the composition effect of plastic drinking bottle waste matrix and rice huskrice husk ash particle with glycerol addition as plastisizer on tensile strength of hybrid composite obtained.

\section{Theory}

Plastic is polymer material that could not easily decompose by decomposer microorganism. Therefore, used plastic piling will cause environmental problem [9]. Nowadays, plastic waste has become main problem in society and can be found in various places, especially in waste disposal. Plastic waste can cause environmental pollution because of its low biodegradability [4] 


\section{International Journal of Science and Research (IJSR) \\ ISSN (Online): 2319-7064}

Index Copernicus Value (2013): 6.14 | Impact Factor (2015): 6.391

The purpose of hybridization is to form new material that maintain the advantages of its constituent and minimize its disadvantages. Hybridization can provide benefits in cost and improvement of the mechanical properties. Therefore, the production cost in producing eco-friendly product can be reduced [7].

Husk is categorized as usable biomass for various needs such as industrial raw material, animal feed, and fuel energy resources. According to the chemical composition data, husk contains various essential chemical elements as shown in Table 1.

Table 1: Chemical Composition of Rice Husk [8]

\begin{tabular}{|c|c|}
\hline Component & Weight (\%) \\
\hline Water content & $32,40-11,35$ \\
\hline Protein & $1,70-7,26$ \\
\hline Fat & $0,38-2,98$ \\
\hline Free nitrogen extract & $24,70-38,79$ \\
\hline Fiber & $31,37-49,92$ \\
\hline Ash & $13,16-29,04$ \\
\hline Pentose & $16,94-21,95$ \\
\hline Cellulose & $34,34-43,80$ \\
\hline Lignin & $21,40-46,97$ \\
\hline
\end{tabular}

Rice husk ash produced from controlled combustion at high temperature $\left(500-600^{\circ} \mathrm{C}\right)$ will produce silica ash that can be utilized in various chemical process. Controlled combustion at temperature higher than $1000^{\circ} \mathrm{C}$ will lead to the production of crystalline silica[9]. Silica content in rice husk ash is approximately $86 \%-97 \%$ dry weight. According to chemical composition data, rice husk ash contains some essential chemical elements as shown in Table 2.

Table 2: Chemical Composition of Rice Husk Ash [8]

\begin{tabular}{|c|c|}
\hline Component & Weight (\%) \\
\hline $\mathrm{SiO}_{2}$ & $86,90-97,30$ \\
\hline $\mathrm{K}_{2} \mathrm{O}$ & $0,58-2,50$ \\
\hline $\mathrm{Na}_{2} \mathrm{O}$ & $0,00-1,75$ \\
\hline $\mathrm{CaO}$ & $0,20-1,50$ \\
\hline $\mathrm{MgO}$ & $0,12-1,96$ \\
\hline $\mathrm{Fe}_{2} \mathrm{O}_{3}$ & $0,00-0,54$ \\
\hline $\mathrm{P}_{2} \mathrm{O}_{5}$ & $0,20-2,84$ \\
\hline $\mathrm{SO}_{3}$ & $0,10-1,13$ \\
\hline $\mathrm{Cl}$ & $0,00-0,42$ \\
\hline
\end{tabular}

Glycerol is the simplest glyceride compound with hydrophilic and hygroscopic hydroxyl. Glycerol is the component which composes various kinds of lipid includes triglyceride [11]. At low glycerol content, the constructed polymer has brittle structure which indicates weak and inflexible characteristics [12]. Theoretically, plasticizer can lower internal force among polymer chains which leads to the decrease of stiffness and improvement of moisture permeability [6].

Extrution is continuous manufacture process used to form long products with fixed sections. This technique can be used for processing most of the thermoplastic polymer and some thermoset polymer. Generally, plastic that can be processed using extrution method has high viscosity so that extruded product can maintain its form until fast cooling step achieved (water bath, air quench atau chill roll) [13].

\section{Methodology}

\section{Materials and Equipment}

The materials used in this research were rice husk and rice husk ash as fillers which ere obtained from Kilang Padi Ginting Jl. Tanjung selamat, Medan Tuntungan. Plastic drinking bottle waste as matrix was obtained from junk collectors around University of Sumatera Utara and Setia Budi Medan. Glycerol 99,7\% as plasticizer was obtained from UD Rudang Jaya Jl. Dr. Mansyur, Medan, Sumatera Utara. The equipment used was Ball Mill, Extruder, Hotpress, Dumbbell Cutter, sieve, tensile strength test equipment, Scanning Electron Microscope (SEM), and Fourier Transform Infra-Red (FTIR).

Preparation of Hybrid Composite PET Plastic Drinking Bottle Waste Filled by Rice Husk-Rice Husk Ash with The Addition of Glycerol as Plasticizer

Rice husk was milled and sieved until 100 mesh particles obtained. Rice husk was dried in the oven at $70^{\circ} \mathrm{C}$ [1] to reduce water content in rice husk particles. Rice husk ash was directly sieved until 100 mesh particles obtained and followed by drying process in the oven at $70^{\circ} \mathrm{C}$. Plastic drinking bottle waste was washed and cut into smaller pieces using scissor.

The ratio between rice husk and rice husk ash particle was 1:1 (w/w). The ratio between plastic drinking bottle waste and rice husk- rice husk ash particles was 95:5, 90:10 and $85: 15$ (w/w). Glycerol addition as much as $3 \%$ of the plastic drinking bottle waste volume was $2.06 \mathrm{ml} ; 1.956 \mathrm{ml}$; dan $1.847 \mathrm{ml}$. Then they were put into beaker glass and stirred until homogeneous mixture obtained. The mixture of rice husk and rice husk ash particle was smelted in extruder at $265^{\circ} \mathrm{C}$. The extruded mixture then was formed into specimen according to ASTM D 638-10. It was done by placing and pressing the filled former in hotpress at $265^{\circ} \mathrm{C}$ for 5 minutes. Then the cooling step was carried out at $25^{\circ} \mathrm{C}-30^{\circ} \mathrm{C}$ for $5-10$ minutes so that the specimen was not too hot when the composite was released from its former. The composite specimens which were released form the formers were tested and characterized using tensile strength test equipment, SEM and FTIR.

\section{Results and Discussion}

FTIR characteristic of rice husk-rice husk ash filled plastic drinking bottle waste hybrid composite with the addition of glycerol as plasticizer can be seen in Figure 1.

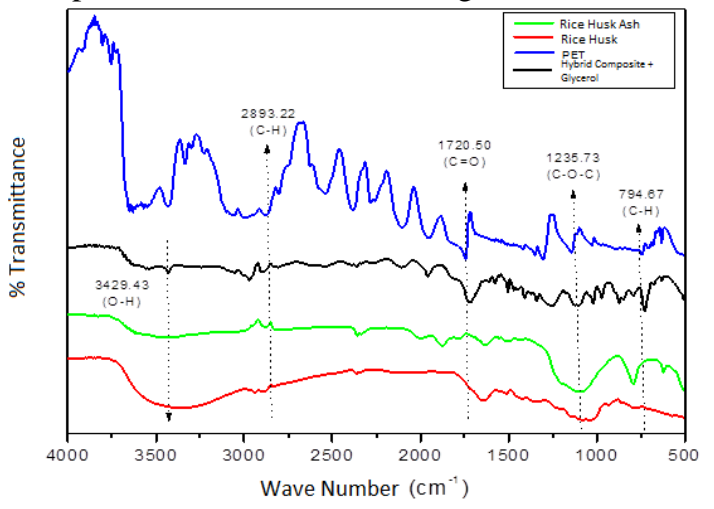




\section{International Journal of Science and Research (IJSR) \\ ISSN (Online): 2319-7064 \\ Index Copernicus Value (2013): 6.14 | Impact Factor (2015): 6.391}

Figure 1: FTIR Characterization of Rice Husk-Rice Husk Ash Filled Plastic Drinking Bottle Waste Hybrid Composite with the Addition of Glycerol as Plasticizer

Figure 1 shows that the presence of wave number at 3429.43 $\mathrm{cm}^{-1}$ indicates hydroxyl (-OH) functional groups from stretched alcohol of cellulose chain and lignin. Wave number at $2966.52 \mathrm{~cm}^{-1}$ indicates $\mathrm{C}-\mathrm{H}$ functional groups from stretched alkane and wave number at $1720.50 \mathrm{~cm}^{-1}$ indicates $\mathrm{C}=\mathrm{O}$ functional groups from stretched carbonyl and acetyl of xylane component from pentose and lignin [14]. Wave number at $1099.43 \mathrm{~cm}^{-1}$ indicates $\mathrm{C}-\mathrm{O}-\mathrm{C}$ functional groups from stretched etherof lignin and pentose whereas wave number at $729.09 \mathrm{~cm}^{-1}$ indicates $\mathrm{C}-\mathrm{H}$ from bend aromatic ring of benzene [15].

From Figure 1, it can also be seen that there is no new absorption peak formed comparing to the FTIR characterization of PET plastic drinking bottle waste and rice husk-rice husk ash filled hybrid composite. This condition shows that the hybrid composite did not undergo any chemical reaction. The combination between the matrix and fillers was only achieved by physical reaction.

Figure 2 shows the effect of rice husk-rice husk ash with glycerol as plasticizer addition into PET plastic drinking bottle waste matrix on the tensile strength of hybrid composite.
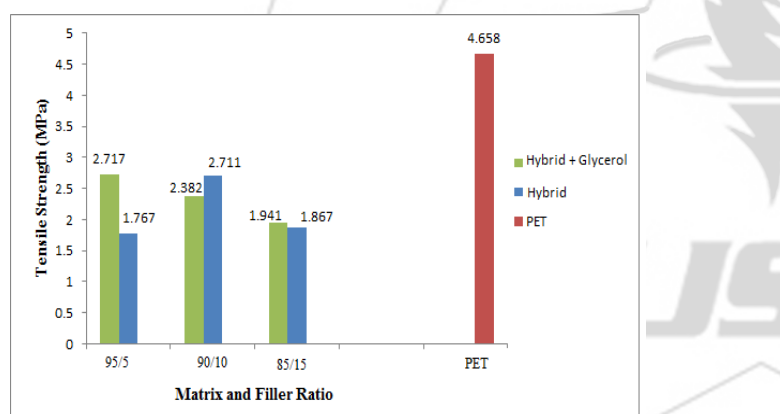

Figure 2: The Effect of Rice Husk-Rice Husk Ash with Glycerol as Plasticizer Addition on the Tensile Strength of PET Plastic Drinking Bottle Waste Matrix Hybrid Composite

From Figure 2, it can be seen that the tensile strength of either hybrid composite or glycerol-filled hybrid composite at all ratio is lower than that of PET plastic drinking bottle waste. It is due to the addition of fillers will cause the decrease of composite's tensile strength. The tensile strength test result shows that the maximum tensile strength obtained for glycerol filled hybrid composite at $95 / 5$ ratio is 2.717 $\mathrm{MPa}$, while hybrid composite without glycerol addition has the maximum tensile strength at $90 / 10$ ratio and get the value of $2.711 \mathrm{MPa}$. These maximum tensile strength obtained are lower than the tensile strength of PET plastic drinking bottle waste which get value of $4.658 \mathrm{MPa}$.

The decrease of tensile strength value in hybrid composite and glycerol filled hybrid composite is due to the weak bonding between hydrophobic polymer matrix and hydrophilic fillers. The agglomeration of fillers are also create an inhomogeneous distribution among matrix [16]. This condition will make the interphase area weak, thus decreasing the strength of composite material to receive stress. Besides, the addition of glycerol in hybrid composite is also contribute for lowering the tensile strength. It is due to the low molecular weight of glycerol $(92.02 \mathrm{~g} / \mathrm{mol})$ which enables it to enter polymer chains easily and improves the flexibility of hybrid composite [17].

The same result had ever been reported by Shivappa et al. (2013) [18] for using different matrix and filler in reinforcing the composite at tensile strength test.

Figure 3 shows the effect of rice husk-rice husk ash filler with glycerol addition on elongation at break of PET plastic drinking bottle waste and rice husk-rice husk ash filled hybrid composite plastic drinking bottle waste.

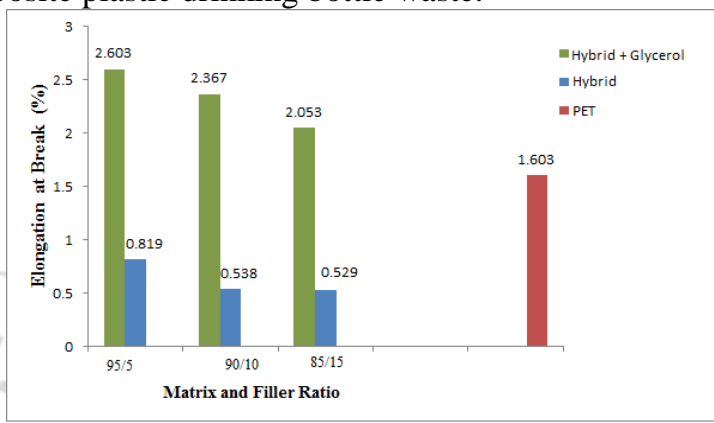

Figure 3: The Effect of Rice Husk-Rice Husk Ash with Glycerol Addition on Elongation at Break of PET Plastic Drinking Bottle Waste Hybrid Composite

Composite testing results show that elongation at break decreases as the filler addition ratio either for hybrid composite or glycerol filled hybrid composite increases. The elongation at break decreasion indicates the reduction of matrix ability to retain stress transfer from polymer material towards the fillers. It is due to the addition of rice husk-rice husk ash filler into the matrix will make a weak bond, thus reducing the elasticity of matrix which will lead to the stiffness of the composite [19]. This condition shows that the increament of fillers will lead to the stiffness of composite material.

Generally, the high elasticity of a material can be indicated from the high elongation at break value. Incorporation of fillers will cause the matrix loss its elasticity. It is due to the restriction of matrix mobility and deformability caused by filler addition [20]. However, glycerol addition into hybrid composite will lead to the improvement of its elasticity. It can be seen in Figure 3 that glycerol filled hybrid composite has higher elongation at break value than PET plastic drinking bottle waste. Glycerol addition will enhance mobility of polymer chain molecular which is shown by the inprovement of composite elasticity, thus the elongation at break value tends to increase [21].

Modulus Young value of rice husk-rice husk ash filled hybrid composite with glycerol addition as plasticizer can be seen in Table 3. Modulus Young is a parameter which indicates the stiffness characteristic of a material. Low modulus young value signify the flexible material, while high modulus young value signify the stiff and rigid material [22].

Table 3: Modulus Young Value of Rice Husk-Rice Husk Ash Filled Hybrid Composite with The Addition of Glycerol as Plasticizer.

\begin{tabular}{|l|l|} 
Material & Modulus Young [MPa] \\
\hline
\end{tabular}




\section{International Journal of Science and Research (IJSR) \\ ISSN (Online): 2319-7064}

Index Copernicus Value (2013): 6.14 | Impact Factor (2015): 6.391

\begin{tabular}{|l|c|}
\hline Hybrid Composite + Glycerol (95/5) & 98.964 \\
\hline Hybrid Composite + Glycerol (90/10) & 102.039 \\
\hline Hybrid Composite + Glycerol (85/15) & 105.134 \\
\hline
\end{tabular}

Table 3 shows that the rice husk-rice husk filled hybrid composite with the addition of glycerol at 95/5 ratio has the lowest modulus young value, while the hybrid composite at $85 / 15$ ratio has the highest modulus young value. This condition shows that the higher incorporation of rice huskrice husk ash filler ratio into PET plastic drinking bottle waste matrix will tend to increase the stiffness and rigidity of the composite. On the other hand, glycerol addition can improve the elasticity of composite, thus lowering the stiffness and rigidity of the plastic drinking bottle waste matrix composite [21].

Fractured surface morphology characterization can be shown using Scanning Electron Microscopy (SEM) Analysis. Figure 4 shows the fractured morphology of PET plastic drinking bottle waste, rice husk-rice husk ash filled plastic drinking bottle waste hybrid composite with the addition of glycerol as plasticizer at $95 / 5$ and $85 / 15$ ratio with $1500 x$ magnification.

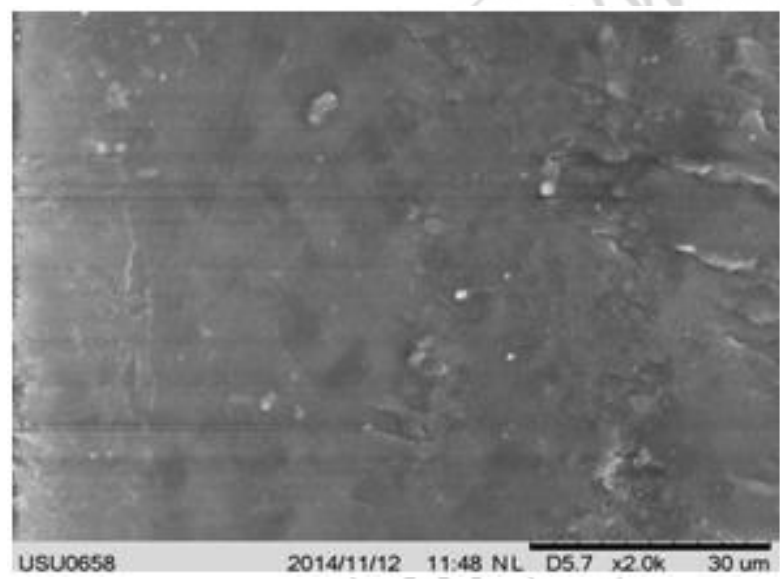

(a)

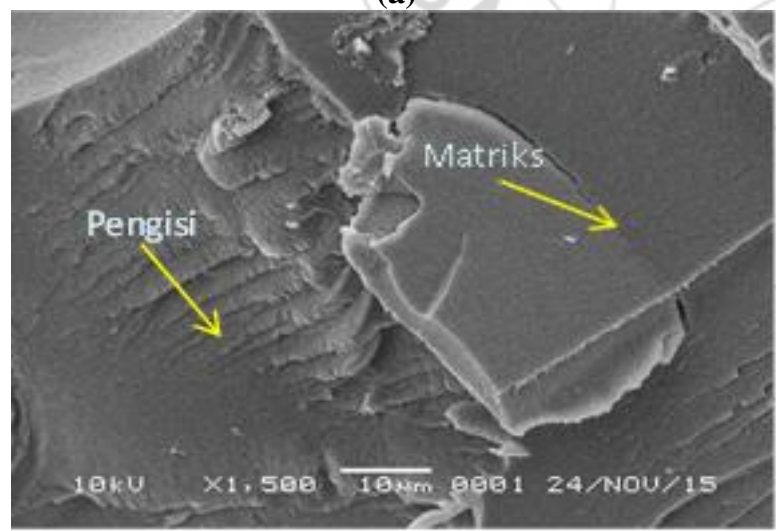

(b)

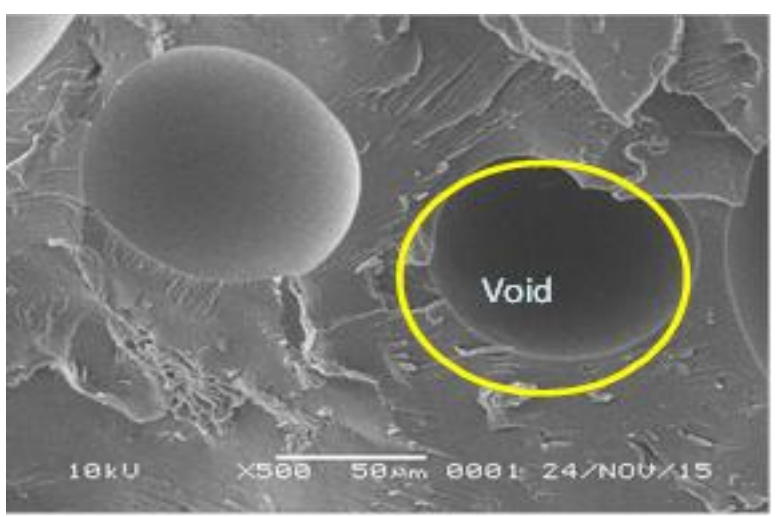

(c)

Figure 4: Scanning Electron Microscopy Images for Fractured Morphology Analysis of : (a) PET Plastic Drinking Bottle Waste with 2000x Magnification; (b) Rice Husk-Rice

Husk Ash Filled Plastic Drinking Bottle Waste Hybrid Composite with The Addition of Glycerol at 95/5 Ratio with 1500x Magnification; (c) Rice Husk-Rice Husk Ash Filled Plastic Drinking Bottle Waste Hybrid Composite with The Addition of Glycerol at 85/15 Ratio with 1500x Magnification

It can be seen from Figure 4(a) that tensile strength testfractured morphology of PET plastic drinking bottle waste has stiff and rigid structure. Figure 4(b) shows that fractured morphology of ice husk-rice husk ash filled PET plastic drinking bottle waste hybrid composite with the addition of glycerol as plasticizer at $95 / 5$ ratio has a good filler distribution, no agglomeration and good interface bond between the matrix and fillers. Figure 4(c) shows that fractured morphology of ice husk-rice husk ash filled PET plastic drinking bottle waste hybrid composite with the addition of glycerol as plasticizer at 85/15 ratio has inhomogeneous filler distribution and the presence of void. Sedangkan Gambar 4(c) menunjukkan morfologi patahan dari Komposit Hibrid PET LBPKM- Abu Sekam Padi dan Sekam Padi dengan penambahan gliserol sebagai plasticizer pada rasio 85/15 menunjukkan bahwa penyebaran pengisinya tidak merata dan terdapat fraksi kosong (void) di dalamnya.The void presence can influence the bonding between matrix and the filler particle. The presence of void in particle will cause the matrix unable to fill the empty space in the former. When the load is applied on the composite, stress area will move ro void area, thus decreasing the strength of composite [23].

\section{Conclusion}

FTIR analysis result of PET plastic drinking bottle waste and rie husk-rice husk ash filled PET plastic drinking bottle waste hybrid composite with the addition of glycerol as plasticizer shows no significant changes in functional groups due to the absence of reaction during mixing process. The addition of glycerol as plasticizer still unable to improve the rice huskrice husk ash filled PET plastic drinking bottle waste hybrid composite at all different ratio comparing to that of PET plastic drinking bottle waste. From the elongation at break analysis result of rice husk-rice husk ash filled PET plastic drinking bottle waste hybrid composite, elongation at break 


\section{International Journal of Science and Research (IJSR) \\ ISSN (Online): 2319-7064}

Index Copernicus Value (2013): 6.14 | Impact Factor (2015): 6.391

characteristics will increase with the addition of glycerol as plasticizer, but decerasing as the filler ratio increases.

\section{References}

[1] Nurdin, Hendri. 2008. Pengaruh Penggunaan Jenis Serat Pada Komposit Polimer Terhadap Kekuatan Tarik. Staff Pengajar Teknik Mesin Universitas Negeri Padang, Zona Teknik, ISSN 1978 - 1741, Volume 3 No. 2: 143-150.

[2] Harris, Bryan. 1999. Engineering Composite Materials. The Institute of Material, London. page : 51[3] Awal, A.S.M. Abdul and Siew Kiat Nguong, A Short-Term Investigation On High Volume Palm Oil Fuel Ash (Pofa) Concrete, 35th Conference on Our World In Concrete \& Structures: Singapore, 25-27 August, 2010.

[3] Mustika, Diana Sari and Dadang Setiyawan. 2011. Peluang Bisnis Pemanfaatan Limbah Botol Plastik Menjadi Aneka SouvenirHajatan. Seminar Hasil Penelitian dan Pengabdian kepada Masyarakat. Fakultas Keguruan dan Ilmu Pendidikan Universitas Veteran Bangun Nusantara Sukoharjo.

[4] Baghaee, Taher, Moghaddam, Mohamed Rehan Karim and Mehrtash Soltani. 2013. Utilization Of Waste Plastic Bottles In Asphalt Mixture. Journal of Engineering Science and Technology, Vol. 8, No. 3 Page: $264-271$.

[5] Laksono, Andhi Putro. 2007. Abu Sekam Padi Sebagai Sumber Silika Pada Sintesis Zeloit ZSM-5 Tanpa Menggunakan Templat Organik. Akta Kimindo, Vol. 3, No.1 Oktober $2007: 33-36$.

[6] N. Gontard, S. Guilbert and J. L. Cuq, Water and Glycerol As Plasticizer Affect Mechanical and Water Vapor Barrier Properties of Edible Wheat Gluten Film. J Food Sci, Vol. 58 (1), pp. 206 - 211, 1993.

[7] Subagia, Ary, I.D.G dan Yonjig Kim. 2013. A Study On Flexural Properties Of Carbon-Basalt/Epoxy Hybrid Composites. Journal of Mechanical Science and Technology. Page: 987 992.

[8] Clary, Ema Decy Ria Tambunan. 2012. Pengembangan Metode Alir Menggunakan Silica Gel Dari Sekam Padi Untuk Mengatasi Logam Berat Cb (II) dan Zn (II). Program Studi Kimia, Fakultas Matematika Dan Ilmu Pengetahuan Alam, Universitas Negeri Medan, Medan.

[9] Bakri, 2008. Komponen Kimia dan Fisik Abu Sekam Padi Sebagai SCM untuk Pembuatan Komposit Semen. Jurnal Parennial, 5(1) : 9-14.

[10]Fajar Galang Agung M., Muhammad Rizal Hanafie Sy., Primata Mardina. 2013. Ekstraksi Silika Dari Abu Sekam Padi Dengan Pelarut KOH. Program Studi Teknik Kimia, Fakultas Teknik, Universitas Lambung Mangkurat, Konversi, Volume 2 No. 1.

[11] http://id.wikipedia.org/wiki/Gliserol. Accessed on January $27^{\text {th }}, 2015$.

[12] Myllarinen, Effect of Glycerol on Behaviour of Amylose and Amylopectin Films. Carbohydrate Polymers, Vol.50, pp. 355-361, 2002.

[13]PT Tri Polyta Indonesia Tbk. Pembuatan Kain NonWoven Ekstrusi Pipi (Pipe Extrusion). Polypropyline Manufacture.

[14] Ahmad, Ishak., Dayang Ratnasari Abu Bakar, Siti Noradilah Mokhilas and Anita Raml. 2007. Direct Usage Of Products Of Poly(Ethylene Terephthalate) Glycolysis For Manufacturing Of Rice Husk/Unsaturated Polyester
Composite. Iranian Polymer Journal, Volume 16, No. 4, Page : 233-239.

[15]Pavia, D.L., Lampman, G.M., Kriz, G.S., 2001. Introduction To Spectroscopy : A Guide for Students of Organic Chemistry. Singapore : Brooks/Cole Thomson Learning, Page 26.

[16] Turmanova, Sevdalina., Svetlana Genieva \& Lyubomir Vlaev, 2012. Obtaining Some Polymer Composites Filled with Rice Husks Ash-A Review. International Journal of Chemistry; Vol. 4, No. 4, ISSN: 1916-9698 EISSN : 1916-9701

[17] Nigsih, Sri Hartuti. 2015. Pengaruh Plasticizer Gliserol Terhadap Karakteistik Edible Film Campuran Whey dan Agar. Program Studi Peternakan. Fakultas Peternakan Universitas Hasanuddin. Makassar.

[18] Shivappa,Dr., Ananda.G.K, Shivakumar.N., 2013. Mechanical Characteisation Of Rice Husk Flour Reinforced Vinylester Polymer Composite. International Journal of Innovative Research in Science, Engineering and Technology. ISSN: 2319-8753 Vol. 2, Issue 11.

[19] Tarmizi, Danil., Kartini Noor Hafni , A. Haris Simamora, 2014. Sifat-Sifat Mekanik Komposit Polipropilena Berpengisi Abu Pembakaran Biomassa Kelapa Sawit. Jurnal Teknik Kimia USU, Article in Press.

[20] Ibrahim, M. S., S.M. Sapuan and A.A. Faieza, 2012. Mechanical And Thermal Properties Of Composites From Unsaturated Polyester Filled With Oil Palm Ash. Journal of Mechanical Engineering and Sciences (JMES) e-ISSN: 2231-8380; Volume 2, Page : 133-147.

[21] R. F Sinaga, G. M. Ginting, M. H. S. Ginting and R. Hasibuan. 2014. Pengaruh Penambahan Gliserol terhadap Sifat Kekuatan Tarik Dan Pemanjangan Saat Putus Bioplastik Dari Pati Umbi Talas. Jurnal Departemen Teknik Kimia USU, Medan.

[22] Hameed, A.M., 2012. Effect of Water Absorption on Some Mechanical Properties of Unsaturated Polyester Resin/ Natural Rubber Blends. Jordan Journal of Physics Volume 5, No. 3, Page : 119-127.

[23] Schwartz, M. M.,. 1984. Composite Materials Handbook. New York : McGraw Hill Book Company. Page 76. 